\title{
City marketing research: a bibliometric analysis
}

Fecha de recepción: 31 de julio de 2019

Fecha de aprobación: 02 de diciembre de 2020

Fecha de publicación: 12 de abril de 2021

Cómo citar este artículo / To reference this article / Comment citer cet article / Para citar este artigo:

Osorio-Andrade, C. F.; Murcia-Zorrilla, C. P.; Arango-Espinal, E. (2020). City marketing research: a bibliometric analysis. Revista Escuela de Administración de Negocios, (89), 113-130. DOI: https://doi.org/10.21158/01208160.n89.2020.2838

\begin{abstract}
City marketing (CM) refers to the practice of promoting and selling cities, towns or regions to a specific target market. In recent years, the academic, political, and managerial interest in CM has grown steadily, becoming one of the fastest growing fields within the marketing and study of tourism. From this perspective, the aim of this research is to analyze the body of literature developed around CM, in order to construct indicators for scientific production. Specifically, the study made use of the bibliometrics and the database Web of Science, utilizing the terms city marketing and city branding as search terms in a non-exclusive manner. It also identifies the evolution of the scientific production, the main academic journals, the most prolific and highly cited authors, the areas of knowledge involved in the CM field, and the concepts or topics that have been most intensively studied. The results suggest that CM studies have increased since 2015, as the scientific journals that publish most research in the field have improved their Scimago Journal and Country Rank (SJR) classification; in addition, it was possible to establish that most of these articles belong to English-speaking and European countries.
\end{abstract}

Keywords: city marketing; city branding; tourism marketing; scientific production.

\footnotetext{
Publicist - Universidad Autónoma de Occidente. Master in Organization Sciences- Universidad del Valle. ORCID: https://orcid. org/0000-0002-5095-4991

2 ndustrial Engineer - Universidad del Valle. Master in Marketing - Universidad Libre. Candidate for the Doctor of Information and Knowledge Society - Universitat Oberta de Catalunya. ORCID: https://orcid.org/0000-0002-5387-9210

3 Certified Public Accountant- Universidad del Valle. Master in Administrative Law - Unviersidad Libre. Candidate for the Doctor of Administration - Universidad del Valle. ORCID: https://orcid.org/0000-0002-2231-3513
} 


\section{Investigación en city marketing: un análisis bibliométrico}

\section{Resumen}

El marketing de ciudades (MC) hace referencia a la práctica de promocionar y vender ciudades, pueblos o regiones a un mercado objetivo específico. En los últimos años, el interés académico, político y gerencial en el MC ha crecido de manera sostenida, convirtiéndose en uno de los campos de más rápido crecimiento dentro del mercadeo y el estudio del turismo. Bajo esta óptica, el objetivo de esta investigación es analizar el cuerpo de literatura desarrollada alrededor del $\mathrm{MC}$ con el fin de construir indicadores de producción científica. Concretamente, se hace uso de la bibliometría y la base de datos Web of Science, en la que se emplearon los términos de búsqueda city marketing y city branding de manera no excluyente. Así mismo, se identifica la evolución de la producción científica, las principales revistas académicas, los autores más prolíficos y de mayor citación, las áreas del conocimiento que intervienen en el campo del MC y los conceptos o tópicos que se han estudiado con mayor ahínco. Los resultados sugieren que los estudios de MC han aumentado desde el 2015, pues las revistas científicas que publican una mayor cantidad de investigaciones en el campo han mejorado su clasificación SJR (Scimago Journal and Country Rank); además, se pudo establecer que la mayor cantidad de artículos desarrollados pertenecen a países angloparlantes y europeos.

Palabras clave: city marketing; city branding; marketing de ciudades; mercadeo del turismo; producción científica.

\section{Pesquisa em marketing urbano: uma análise bibliométrica}

\section{Resumo}

$\mathrm{O}$ marketing de cidades $(\mathrm{MC})$ refere-se à prática de promover e vender cidades, vilas ou regiões a um mercado-alvo específico. Nos últimos anos, o interesse acadêmico, político e administrativo no MC tem crescido continuamente, tornando-se um dos campos de crescimento mais rápido no marketing e no estudo do turismo. Nessa perspectiva, o objetivo desta pesquisa é analisar o corpo bibliográfico desenvolvido em torno do MC a fim de construir indicadores de produção científica. Especificamente, utiliza-se a bibliometria e a base de dados Web of Science, em que os termos de busca city marketing e city branding foram utilizados de forma não exclusiva. Do mesmo modo, identifica-se a evolução da produção científica, as principais revistas acadêmicas, os autores mais prolíficos e mais citados, as áreas do conhecimento que intervêm no campo do $\mathrm{MC}$ e os conceitos ou temas que foram estudados com maior determinação. Os resultados sugerem que os estudos do MC aumentaram desde 2015, pois as revistas científicas que publicam uma maior quantidade de pesquisas na área melhoraram sua classificação SJR (Scimago Journal and Country Rank), além disso, constatou-se que o maior número de artigos desenvolvidos pertence a países de língua inglesa e europeus.

Palavras-chave: marketing urbano; city branding; marketing de cidades; marketing turístico; produção científica. 


\section{Etude de mercatique urbaine: une analyse bibliométrique}

\section{Résumé}

La mercatique urbaine (MU) fait référence à la promotion des villes et des régions pour un marché spécifique. Ces dernières années, l'intérêt académique, politique et entrepreneurial pour la MU a pris de l'ampleur, devenant l'un des domaines de croissance les plus rapides du marketing et de l'étude touristique. Cet article a pour but d'analyser l'ensemble de la littérature ayant pour objet la MU afin de construire des indicateurs de production scientifique. Nous utiliserons la bibliométrie et la base de données Web of Science dans laquelle les termes de «city marketing» et «city branding» sont utilisés de manière non exclusive. L'étude tentera d'identifier l'évolution de la production scientifique, les principales revues académiques, les auteurs les plus prolifiques et les plus cités, les domaines de connaissances qui interviennent dans le domaine de la MU et les concepts les plus étudiés. Les résultats suggèrent que les investigations en $M U$ ont augmenté depuis 2015 et que les revues scientifiques publient davantage de recherches dans ce domaine pour améliorer par la même occasion leur classement SJR (Scimago Journal and Country Rank). Nous constatons enfin que les publications les plus nombreuses appartiennent à des pays anglophones et européens.

Mots-clés: mercatique urbaine; image de marque des villes; marketing touristique; production scientifique. 


\section{Introduction}

$\mathrm{T}$ The concept of city marketing, city branding, or place marketing refers to the practice of recognizing, positioning, promoting, and selling cities, towns, regions, and countries to a specific market, by means of a positive city image. In other words, it is the marketing strategies aimed at building and redefining the image of certain specific locations (Nagy, 2015; Smyth, 2005). City marketing is also defined in the literature as a customer-oriented marketing tool so as to build, communicate, deliver, and exchange values for the consumers of a city and the urban community in general (Eshuis, Braun, Klijn, \& Zenker, 2018).

Cities have always felt the imperative need to stand out from the rest in order to assert their individuality, owing to various economic factors and their political or socio-psychological objectives (Kavaratzis \& Ashworth, 2005). Expressed differently, the conscious attempt of municipal administrations to give identity to a place that has been specifically designed for promotion to potential markets, whether external, internal or mixed, is almost as old as the very notion of city (Kavaratzis \& Ashworth, 2005).

However, the increasing competition among cities, countries, and regions caused by the globalization of markets, tourism growth, and the intensification of mobile resources, have stimulated the interest in city marketing, leading this type of practices to become a common activity for almost all municipal governments (Capone \& Lazzeretti, 2016; Zhang \& Zhao, 2009).

The literature suggests that city marketing increases the value of a specific location for investors, tourists, and residents by means of the development of the environment, infrastructure, and communication (Kotler \& Gertner, 2002). In short, it is a commercial activity that promotes and sells urban spaces with a view to attract and retain visitors, residents, and investing organizations. Within the city marketing strategies, the city is promoted as if it were a product like any other (Trueman, Klemm, \& Giroud, 2004); therefore, it is advisable to apply all the strategies of the marketing mix in order to build its identity (Lu \& De Jong, 2019), and consolidate its position within the urban administrative hierarchy system (D'Alessandro, Sommella, \& Viganoni, 2015).

Marketing strategies include promoting the global city, the good city, the cosmopolitan city, the green city, the business city, the post-industrial city, and the city of culture; and the tactics incorporate building iconic buildings, slogans, logos, and names (Short, 2015, as cited in Short, 2018). This means that, if a city is presented as a «smart» city, leaders should strive to undertake strategic actions that position their city as such to the international community, mostly to its neighbors and target markets.

Generally speaking, city marketing strategies include landscape intervention, infrastructure development, organization and administrative structure, citizens and stakeholders' behavior, and the creation and communication of an identity through a consolidated brand image that must be exposed in different public scenarios (Casidy \& Wymer, 2015; Hospers, 2010; Kavaratzis \& Ashworth, 2007). Local identity should be strengthened, stakeholders should be engaged, and even the opinion of tourists should be taken into account for local brand building (Dai, Hein, \& Zhang, 2019).

Despite the fact that city marketing emerges from within the heart of marketing, theorists such as Henninger, Foster, Alevizou, and Frohlich (2016) argue that it is a complex concept that involves political science and economics. On the one hand, some authors have been concerned with studying the political dimension of city marketing, which involves democracy, legal processes, and stakeholder participation in the transformation of the identity of a city (Henninger et al., 2016; Kavaratzis \& Kalandides, 2015); even, some authors argue that city marketing 
favors governance (Klijn, Eshuis, \& Braun, 2012). Moreover, it is considered one of the modern tools to form and strengthen a city brand across the world (Dril, Galkin, \& Bibik, 2016).

On the other hand, certain theorists have focused on the economic dimension of city marketing, considering this practice an essential element that meets the need for competitiveness that cities have in the current economic context (Anttiroiko, 2015). In short, city marketing is a complex process in which political and economic factors exert a profound influence.

Normally, the establishment of a branding strategy for a city is driven from the top down by the members of the city administrations and governors ( $\mathrm{Lu} \&$ De Jong, 2019); however, for their proper functioning, such strategies require the involvement and collaboration of all stakeholders or interested actors (Eshuis et al., 2018; Klijn et al., 2012).

Considering that city marketing is essential to manage perceptions about regions, countries, towns, and cities, it becomes of vital importance to include residents, businesses, and tourists in the branding process (Henninger et al., 2016; Klijn et al., 2012; Zenker \& Braun, 2017). The perception and prestige of the residents of the city are associated with the external perception of the city; therefore, it is necessary to count on the commitment of the inhabitants to boost the city brand, which is not only the responsibility of the municipal administration (Misic \& Podnar, 2019).

As described before, the interest in the theory and practice of city marketing has been advancing in recent years by leaps and bounds within governments and the global scientific community (Green, Grace, \& Perkins, 2016), as stakeholders around the world attempt to manage city brands for various purposes; for example, with a view to strengthen tourism, business, and international relations (Dinnie, 2011; Oguztimur \& Akturan, 2016).
Moreover, in today's world, where technology has increased the levels of development and competition not only among companies, but also among territories, there is a fundamental concern for the development of the city and its logistics (Dril et al., 2016). This growing interest in city marketing is evidenced by a large number of scientific articles published in recent years, in indexed academic databases such as the Web of Science.

The cultivation of a discipline creates the necessity to advance studies that contribute to analyze the body of knowledge that has been accumulated over time, with the aim of evidencing the existing lines of research and identifying study opportunities (Urbizagástegui, 2015). Thus, researches that review the literature become essential sources to find opportunities and research gaps that contribute to the growth of said discipline (Martens, Lacerda, Belfort, \& Rodríguez, 2016).

The idea of analyzing research in the city marketing area is important, as several theorists point out the need to increase understanding in this field of knowledge (Green et al., 2016). Despite the growing number of scientific publications developed in recent years, the literature still considers city marketing as an emerging field (Ahn, Hyun, \& Kim, 2016; Rehmet \& Dinnie, 2013) and of limited theoretical refinement (Oguztimur \& Akturan, 2016). On the other hand, some authors suggest that there is a disconnection between research and practice in the context of city marketing (Kavaratzis \& Kalandides, 2015).

In this regard, when reviewing the literature that addresses the evolution of the concept of city marketing, Green et al. (2016) indicate that its practice has focused on the idea of the city, its development, brand management, promotion, urban governance, and the formalized city; while research has been concerned with analyzing the application and adaptation of the existing theory and the development of critical positions in relation to the city marketing process. From this perspective, they highlight the need to foster a mutual understanding between theory and practice. 
It should also be noted that, although cities take measures to be attractive, differentiation is an increasingly important variable, even for smaller cities that invest large budgets for the purpose of pursuing marketing policies, which in turn allow them to attract new target groups and maintain the existing ones (Goovaerts, Van Biesbroeck, \& Tilt, 2014).

For their part, Oguztimur and Akturan (2016) systematically review 147 papers related to city marketing, and identify four major subject areas in this field: a) city branding concept; b) branding strategies; c) social urbanism; and d) brand culture and tourism. In addition, they point out that most studies related to city marketing are based on qualitative methods that describe data, but do not interpret the relationship between concepts and theories; therefore, knowledge is ideographic.

Similarly, Lucarelli and Olof (2011) analyze and synthesize 217 manuscripts in the field of city marketing, allowing them to specify that the concept emerges as an internationally recognized research domain, characterized by a high level of rapid and interdisciplinary proliferation. These authors identify three lines of research in city marketing: a) city branding; b) city branding consumption; and c) city branding design critique.

Despite the existence of these and other studies that are responsible for analyzing the city marketing research field, there is a lack of analyses that contribute to generate indicators aimed at measuring the literature and evaluating scientific production. In this purpose, bibliometrics can be appealed as they are widely accepted and used to develop metrics in the academic literature (Martens et al., 2016; Okubo, 1997). Given that the main objectives are to help the understanding of the city marketing field and aid researchers to identify study opportunities, this paper applies the bibliometric analysis of scientific articles published in the Web of Science database.

Specifically, this research aims at answering the following questions: Since when have studies related to city marketing been published? Which are the regions or countries with the largest number of publications in this field? Which are the academic areas or disciplines that have dealt with the concept? Which are the indexed academic journals that have published the most studies on city marketing? Which are the most relevant city marketing research articles? and who are the authors with the greatest scientific production? Finally, we hope to offer an overview of the categories for analysis that are evaluated in the study of city marketing, and what the future lines of research could be.

In order to answer the former questions, we analyzed 298 scientific manuscripts representing the total number of papers related to city marketing in the Web of Science database as of June 2019. Furthermore, this paper is divided into four sections, including this introduction. The second section outlines the methodology and data collection process. The third section presents the results of the bibliometric analysis and, finally, the fourth section presents the most relevant conclusions and future lines of research.

\section{Methodology}

$I^{n}$ order to analyze the body of literature developed around city marketing, this research uses bibliometrics, a discipline that is derived from scientometrics, and whose objective is the exploration, retrieval, and analysis of data that facilitate the identification of patterns in the scientific literature. Likewise, bibliometrics finds quantitative and qualitative changes that contribute to establish profiles and trends in the progress of research and scientific development (Rey-Martí et al., 2016). This discipline «has advantages over other literature review methods; particularly, the use of statistical and 
mathematical techniques for the analysis and measurement of the quantity and quality of scientific publications becomes more rigorous» (Durieux \& Gevenois, 2010, p. 342). Figure 1 shows the methodology that was used in this research.

Figure 1. Research model

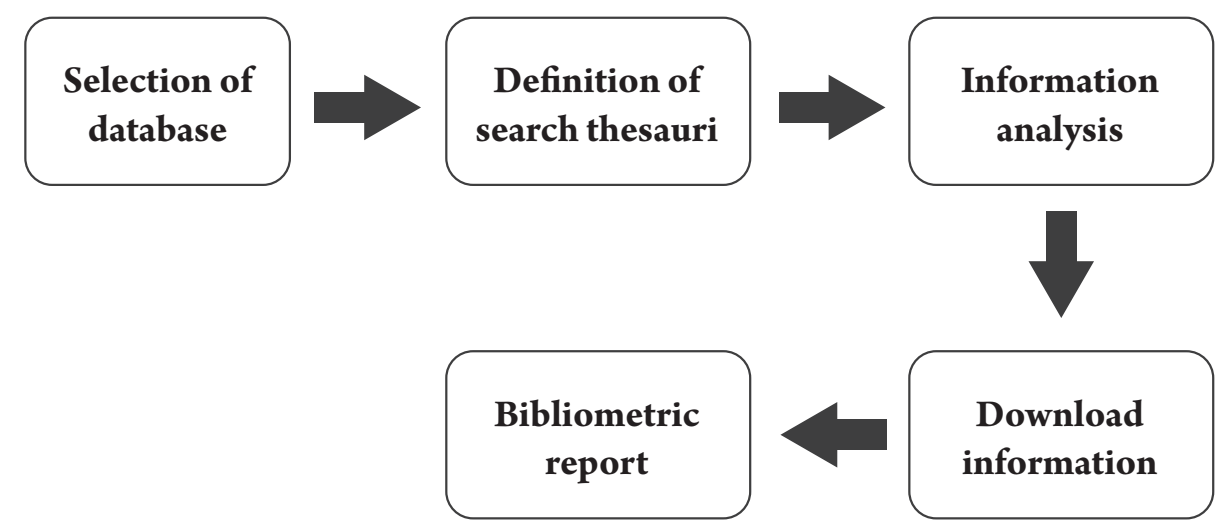

Source. Osorio, 2019.

\subsection{Selection of database}

A transcendental element that influences the success of the bibliometric analysis is the proper selection of the databases from which scientific manuscripts are retrieved (Martens et al., 2016). The availability, reliability, and relevance of the retrieved papers are fundamental factors for the construction of a firstrate bibliometric analysis (Cadavid, Awad, \& Franco, 2012).

Given the above, we selected the database Web of Science (WOS) for this study, because it is positioned as one of the largest and most important databases in the world, with approximately 36 million records in more than 230 scientific disciplines; in addition, it is updated on a daily basis and provides the user with analysis tools that allow an initial evaluation of the literature to be consulted.

\subsection{Procedure and selection of the articles - search criteria-}

The search terms city marketing and city branding were used in a non-exclusive manner. The search was carried out in titles, abstracts, and keywords of academic papers, in a non-simultaneous manner. This means that we looked for any of these concepts to be present in at least one of these fields.
The search was not refined by time period, as the intention of the study was to analyze all the papers on city marketing that were available in the Web of Science database up to June 2019. The procedure yielded a total of 295 articles published in the field of city marketing.

\subsection{Analysis of the information}

To analyze the retrieved manuscripts, we first used the descriptive analysis tools offered by the Web of Science database. Specifically, we generated tables and figures in order to map the following factors: growth trend of publications over time, most important scientific journals, countries with the highest production, most prolific authors, and most cited papers.

For the purpose of identifying the most frequently occurring topics in the field of city marketing and the relationship between the most cited authors, we used the bibliometric package VOSviewer (Waltman \& van Eck, 2015). This software allows to see diagrams that show the topics of highest occurrence in titles, abstracts, and keywords of the chosen articles. In the graphs by VOSviewer, the most relevant elements are observed in larger size; in addition, the closeness between each element evidences the degree of cooccurrence (Waltman \& van Eck, 2015). 


\section{Results}

$\mathrm{T}$ his section presents the results of the bibliometric analysis undertaken. Specifically, we present the growth trend over time indicators for the academic production, the most important scientific journals, countries with the highest production, areas that have addressed city marketing, the most prolific authors, the most cited papers, and concepts of maximum occurrence in the discipline of city marketing.

\subsection{Evolution of the scientific production}

Figure 2 shows the trend in scientific production related to city marketing. It can be seen that, as of 2015, scientific production related to this subject has increased considerably. It can also be seen that the first scientific publication in this field is recorded in 2003, indicating that it is a relatively recent discipline. It should be noted that no conclusive data are presented as of 2019, year of this research.

Figure 2. Number of articles per year

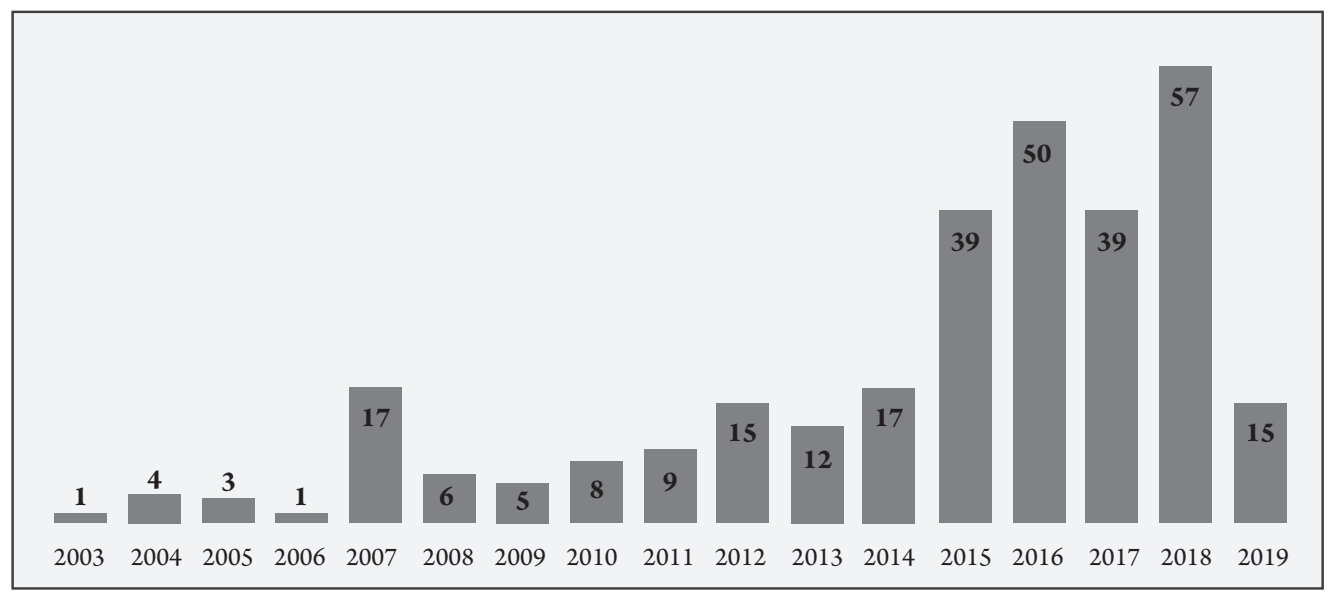

Source. Prepared by the authors based on data from Web of Science.

\subsection{Leading journals in city marketing}

Table 1 shows the ten journals with the highest number of scientific articles published in the area of city marketing. It is interesting to note that six of them belong to the United Kingdom. Besides, one can observe that most of them are indexed in the category of emerging journals, which means that these journals have been increasing their rigor and recognition in recent years. It is also worth noting that one of them is a Colombian journal, with three articles published in the field of city marketing. 
Table 1. City marketing journals

\begin{tabular}{|c|c|c|c|c|}
\hline N.o & Journal & Articles & Country & JCR \\
\hline 1 & Cities & 24 & United Kingdom & Q1 \\
\hline 2 & Place Branding and Public Diplomacy & 13 & United Kingdom & N/A \\
\hline 3 & Journal of Place Management and Development & 9 & United Kingdom & N/A \\
\hline 4 & Sustainability & 7 & Switzerland & Q3 \\
\hline 5 & Urban Studies & 6 & United Kingdom & Q1 \\
\hline 6 & Journal of Destination Marketing Management & 5 & United Kingdom & N/A \\
\hline 7 & Journal of Brand Management & 4 & United Kingdom & Q3 \\
\hline 8 & Transformations in Business Economics & 4 & Lithuania & N/A \\
\hline 9 & Urban Geography & 4 & United States & Q1 \\
\hline 10 & Bitácora Urbano-Territorial & 3 & Colombia & N/A \\
\hline
\end{tabular}

Source. Prepared by the authors based on data from Web of Science.

\subsection{Scientific production by country}

Table 2 shows the top 15 countries with the highest scientific production in the field of city marketing. China appears in first place with 32 academic articles published on this subject, followed closely by England and the United States with 30 and 29 articles, respectively. No Latin American country figures in the list, which demonstrates deficient production on the subject in this region.

Table 2. Scientific production by country

\begin{tabular}{|c|c|c|}
\hline Position & Country & Articles \\
\hline 1 & China & 32 \\
\hline 2 & England & 30 \\
\hline 3 & United States & 29 \\
\hline 4 & Netherlands & 22 \\
\hline 5 & Spain & 22 \\
\hline 6 & Australia & 18 \\
\hline 7 & Germany & 15 \\
\hline 8 & Italy & 12 \\
\hline 9 & Canada & 11 \\
\hline 10 & Poland & 11 \\
\hline 11 & Sweden & 11 \\
\hline 12 & Denmark & 9 \\
\hline 13 & Turkey & 9 \\
\hline 14 & Indonesia & 7 \\
\hline 15 & South Korea & 7 \\
\hline
\end{tabular}

Source. Prepared by the authors based on data from Web of Science. 


\subsection{Areas that have addressed city marketing}

Table 3 lists the 15 areas of knowledge that have most frequently studied city marketing.

Social sciences is in the first place with 66 papers, followed by urban studies with 60 articles and, the area of economic business in third place with 54 manuscripts.

Table 3. Areas of use of city marketing

\begin{tabular}{|c|c|c|}
\hline Position & Country & Articles \\
\hline 1 & General social sciences & 66 \\
\hline 2 & Urban studies & 60 \\
\hline 3 & Business economics & 54 \\
\hline 4 & Geography & 46 \\
\hline 5 & Ecology & 44 \\
\hline 6 & Public administration & 32 \\
\hline 7 & Science technology & 11 \\
\hline 8 & Arts and humanities & 9 \\
\hline 9 & Sociology & 9 \\
\hline 10 & History & 8 \\
\hline 11 & Cultural studies & 7 \\
\hline 12 & Architecture & 5 \\
\hline 13 & Development studies & 5 \\
\hline 14 & Anthropology & 4 \\
\hline 15 & Communication & 4 \\
\hline
\end{tabular}

Source. Prepared by the authors based on data from Web of Science.

\subsection{Authors with the highest production}

Table 4 is built according to the metrics of Web of Science, and it shows the authors with the largest number of published manuscripts in the field of city marketing. Martin De Jong, professor at Delft University of Technology, The Netherlands, tops the list with eight published articles. In his most referenced work -eight citations- De Jong conducts a case study to identify the city marketing practices applied by some Chinese cities in order to position themselves as ecological and economic hotspots $(\mathrm{Lu}$, De Jong, \& Chen, 2017).

In the second place, Professor Chung Shing Chan from the Chinese University of Hong Kong registers five manuscripts indexed in Web of Science. In his most cited article - 13 citations- he explores, together with his co-authors, the role of public parks in the construction of city-brand identity (Chan, Peters, \& Marafa, 2015).
Professor Andrea Insch, from the University of Otago in New Zealand, comes in the third place with the same number of published articles. In her highest impact manuscript -12 citations- this researcher establishes the factors that override the participation and engagement of the residents of the city in brand building (Insch \& Stuart, 2015).

In the fourth place, Professor Mihalis Kavaratzis from the University of Leicester, also with five published papers. His most relevant paper -294 citationssuggests how to apply brand-product building techniques in city-brand building (Kavaratzis \& Ashworth, 2005).

Finally, and again with five articles indexed in Web of Science, Professor Haiyan Lu from the Free University of Berlin ranks fifth in the list. His most cited paper -three citations- is shared with De Jong and Chen; here, they analyze the most successful city positioning strategies by Chinese locations (Lu et al., 2017). 
Table 4. Authors and universities

\begin{tabular}{|c|c|c|c|}
\hline N.o & Author & Institutional affiliation & Articles \\
\hline 1 & De Jong, Martin & Delft University of Technology & 8 \\
\hline 2 & Chan, Chung Shing & Chinese University of Hong Kong & 5 \\
\hline 3 & Insch, Andrea & University of Otago & 5 \\
\hline 4 & Kavaratzis, Mihalis & University of Leicester & 5 \\
\hline 5 & Lu, Haiyan & Free University of Berlin & 5 \\
\hline
\end{tabular}

Source. Prepared by the authors based on data from Web of Science.

\subsection{Most frequently cited papers}

Table 5 is built with information from Web of Science. It presents the articles with the highest number of citations in the field of city marketing. In addition, each of these documents was reviewed qualitatively in order to identify the main topics they address and their contributions.

The work of Kavaratzis and Ashworth (2005) appears in first place with 294 citations; and as mentioned in the previous section, not only it defines the concept of city marketing or city branding, but also proposes brand-product construction techniques that can be effectively applied in the construction of city identity.

The study by Bell and Binnie (2004) took second place among the most referenced articles with 171 citations. This paper analyzes how homosexual people are recruited in the process of urban transformation and, in turn, how city branding becomes part of the sexual citizenship agenda.

Third place is for the theoretical work of Kavaratzis and Hatch (2013) with 142 citations. These authors propose a dynamic vision of city identity, considering it as a constant dialogue between the internal and the external, that is to say, a construction of the interaction between stakeholders.

The manuscript by Zhang and Zhao (2009) reaches the fourth place with 139 citations. It sets out an empirical study that establishes the extent to which the official branding strategies for the Beijing Olympics (2008) captured the positive attributes of the city. As a result, they argue that there was a mismatch between the identity projected in advertising and the reality experienced by tourists and residents.

Finally, the article by Vanolo (2008), with 119 citations, conducted a case study in Turin, Italy, with the aim of empirically identifying how the «creative city» is celebrated and displayed.

With the above information, it can be noted that the most cited works are not related with each other -except for those of Kavaratzis-, and that the qualitative studies, mainly observational, and case studies, largely dominate.

Table 5. Related work

\begin{tabular}{|l|c|c|c|}
\hline \multicolumn{1}{|c|}{ Title } & Year & Author (s) & Citations \\
\hline $\begin{array}{l}\text { «City branding: an effective assertion of identity or a transitory } \\
\text { marketing trick?» }\end{array}$ & 2005 & (Kavaratzis y Ashworth, 2005) & 294 \\
\hline «Authenticating queer space: citizenship, urbanism and governance» & 2004 & (Bell y Binnie, 2004) & 171 \\
\hline $\begin{array}{l}\text { «The dynamics of place brands: an identity-based approach to place } \\
\text { branding» }\end{array}$ & 2013 & (Kavaratzis y Hatch, 2013) & 142 \\
\hline $\begin{array}{l}\text { «City branding and the olympic effect: a case study of Beijing» } \\
\text { «The image of the creative city: some reflections on urban branding in } \\
\text { Turin» }\end{array}$ & 2009 & (Zhang y Zhao, 2009) & 139 \\
\hline
\end{tabular}

Source. Prepared by the authors based on data from Web of Science. 


\subsection{Important research topics in the field of political advertising}

In order to identify the concepts with the highest occurrence in the 298 manuscripts selected, we applied a bibliometric analysis using VOSviewer software (Waltman \& van Eck, 2015).

This program generates a map of the topics covered in the articles, based on the analysis of titles, abstracts, and keywords, allowing to visualize the behavior of the concepts in a diagram, according to their frequency of appearance in the documents and the strength of the bonds among them (Figure 3 ).

Subsequently, we qualitatively reviewed some documents containing the most frequently occurring concepts, in order to identify their importance within the field of city marketing knowledge.

The term with the highest occurrence is City Branding with 123 appearances in the analyzed manuscripts. This term refers to the construction of a brand for a city, and it is the central process within the city marketing strategies; therefore, it is understandable that it appears in the first place. It constitutes the creation of brand identity for a specific place (Merrilees, Miller, \& Herington, 2009).

The word Image -city branding image- appears in 60 documents, which indicates the importance of the construction of the city image within the practice of city marketing (Luque, del Barrio, Ibáñez, \& Rodríguez, 2007; Hassen \& Giovanardi, 2018). Similarly, the concept of Identity - city branding identity- is present in 57 documents, showing that studies in the field of city marketing have considered it a fundamental part of the process of promoting and selling locations (Fan \& Poshinova, 2016; Murwani \& Melati, 2018).
The term Policy is observed in 48 documents. This clearly reflects the transcendental role played by public administrations and governors in the city marketing process (Grubbauer, 2014; McCann, 2013).

The word Culture appears in 40 documents. It suggests the importance of the cultural identity of cities and their stakeholder groups in the development of city marketing strategies (Kozak, Buric, Policar, Hamackova, \& Lepicova, 2007; Vanolo, 2008). Several authors have pointed out that local culture should be respected and reflected in city branding processes (Van Roy, 2007; Zhang \& Zhao, 2009).

The term Resident also stands out with 40 appearances in the literature that was explored. This concept alludes to the influence that city residents have on a successful city marketing process (Merrilees, Miller, \& Herington, 2012). Some investigations maintain that the involvement of residents and all the stakeholders is vital to the development of a city marketing plan (Petrea, Petrea, Olau, \& Filimon, 2013; Zenker \& Petersen, 2014).

It is worth highlighting the term Case Study, which appears in 35 papers. This concept evidences the large amount of research in the field of city marketing that develops case studies with the objective of identifying weaknesses and strengths in cities of wide international recognition (De Jong, Hoppe, \& Noori, 2019; Homan, O’Hanlon, Strong, \& Tebbutt, 2017; Molina, Fernández, Gómez, \& Aranda, 2017); it also suggests the dominance of qualitative studies in the area of city marketing. 
Figure 3. Bibliometric analysis

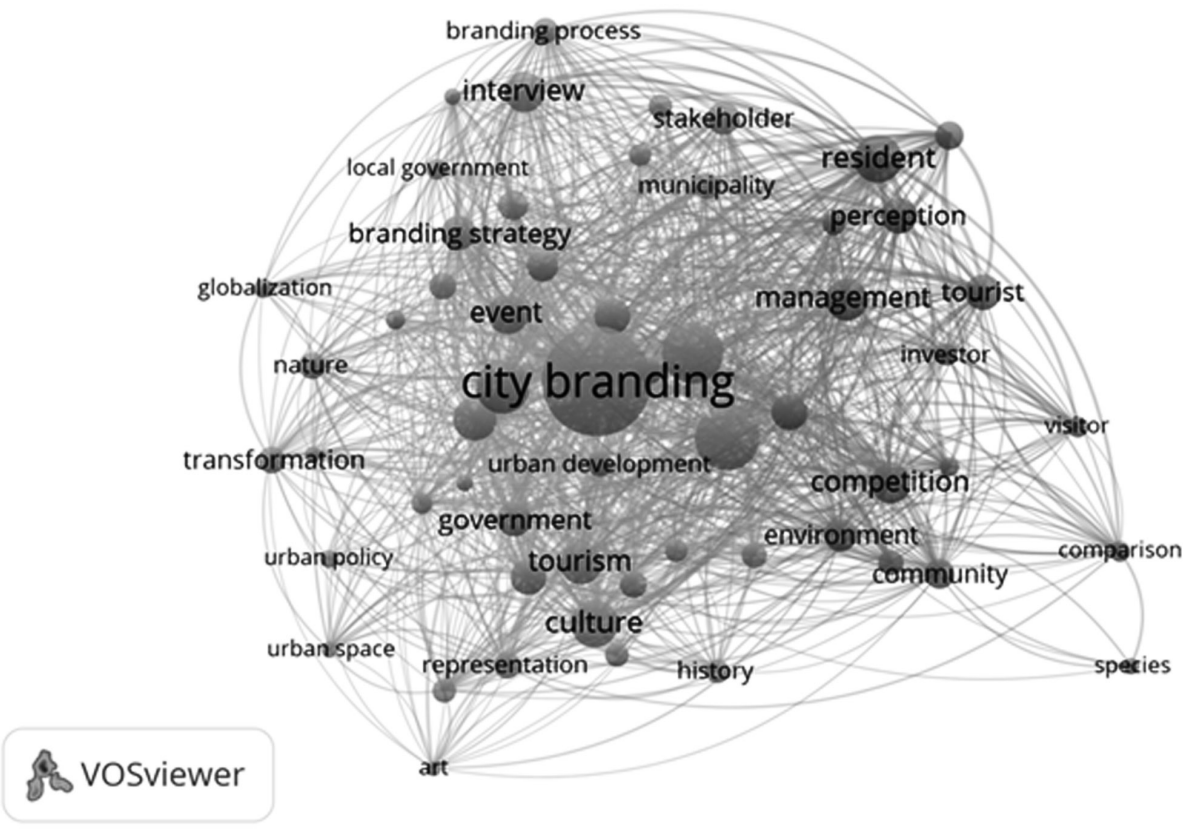

Source. Prepared by the authors.

\subsection{Grouping of terms according to their level of occurrences}

In line with Sassmannshausen and Volkmann (2013) and Martens et al. (2016), referents of the bibliometric techniques, we grouped the terms into three categories according to the frequency of occurrence in the literature explored: high occurrence, moderate occurrence, and low occurrence.

This identifies the concepts that have been mostly used in the scientific literature, as well as those that have recently begun to draw the attention of researchers in city marketing.

Table 6. Term implementation and frequency of appearance

\begin{tabular}{|c|l|}
\hline Frequency of appearance & \multicolumn{1}{c|}{ Terms } \\
\hline $\begin{array}{c}\text { High: topics are mentioned in more than 10\% } \\
\text { of the articles explored. }\end{array}$ & $\begin{array}{l}\text { City branding, city image, city identity, policy, culture, residents, case study, } \\
\text { administration, tourism, competition, event, interview, and perception. }\end{array}$ \\
\hline $\begin{array}{c}\text { Moderate: topics appear in more than 3\% } \\
\text { of the articles explored. }\end{array}$ & $\begin{array}{l}\text { Economy, promotion, brand strategy, municipal government, ecosystem, } \\
\text { stakeholder group, community, place marketing, survey, transformation, lecture, } \\
\text { nature, quality, representation, city services, investment, population density, urban } \\
\text { development, and history. }\end{array}$ \\
\hline $\begin{array}{c}\text { Low: concepts appear in less than 3\% } \\
\text { of the articles explored. }\end{array}$ & $\begin{array}{l}\text { Knowledge, architecture, state, citizens, investors, creation, comparison of cities, } \\
\text { globalization, political marketing, urban policy, content analysis, fauna and flora } \\
\text { diversity, and art. }\end{array}$ \\
\hline
\end{tabular}

Source. Prepared by the authors based on data from Web of Science. 


\section{Conclusions}

$\mathrm{T}$ his research allows drawing relevant conclusions for researchers or those interested in city marketing. First, it is worth noting that studies addressing city marketing as a unit of analysis have steadily increased since 2015, evidencing the importance of city marketing for the global academic community. On the other hand, scientific journals that have published a greater amount of research in the field of city marketing have been improving their SJR classification, suggesting that these types of topics are attracting growing interest.

The analysis of scientific production in city marketing reveals that the countries with the highest academic production are China, England, and the United States; furthermore, with some exceptions such as Indonesia and South Korea, the largest number of articles developed in this field belong to European or English-speaking countries, revealing that no Latin American country is found among those with the highest production in this field.

However, it is important to acknowledge that processes based on city marketing and regional identity have recently been initiated in the Colombian environment, as for example, the coffee cultural landscape (PCC by its abbreviation in Spanish), and Medellin the most innovative, among others, without reporting studies published in Web of Science. This finding provides research opportunities for Latin American scholars who may be interested in city marketing.

It is important to explore successful cases of city branding in Latin American cities and regions, as well as to contrast the findings of theoretical models in other social, economic, and cultural contexts similar to those experienced in Latin America.

This research identifies the works of Bell and Binnie (2004), Kavaratzis and Ashworth (2005), Vanolo (2008), Zhang and Zhao (2009), and Kavaratzis and Hatch (2013) as studies of mandatory review for anyone interested in city marketing. Considering that these are the most cited papers in the city marketing field, they can be thought of as having laid the foundation for the current body of knowledge in this discipline. It is worth remarking that, unlike what happens in other areas of knowledge, the most cited papers generally address different topics, which implies low levels of correlation among them.

It can be seen that the field of city marketing is permeated by a large number of areas of knowledge, making it an interdisciplinary field. Urban studies, geography, business, politics, environmental sciences, and communication, among other sciences and disciplines, have been concerned with studying this concept from different perspectives. In practical terms, this situation offers great research opportunities to those interested in city marketing, since it can be analyzed and studied from a wide range of scientific areas.

The analysis of the most frequently occurring terms in the field of city marketing highlights the concepts of city branding construction, city branding image, and city branding identity as the most important within the field of knowledge. This indicates that most city marketing research has focused on understanding how the city branding construction process works, and how identity and image play a transcendental role in this strategy.

On the other hand, the presence of the term «policy» indicates the importance of city leaders and administrations in developing successful city marketing strategies. Although the involvement of stakeholders plays an important role in the establishment of these policies in city marketing, usually, the will to initiate the process arises from the top down in power bodies (Lu \& De Jong, 2019), as the state encourages entrepreneurship (Mazzucato, 2011). Under this premise, the idea of analyzing the role of local administrations in Latin American cities in the development and success of city marketing strategies sounds interesting. 
It is worth highlighting the importance of the word «culture» within the terms of greatest occurrence, which reinforces the importance of analyzing the processes and cases of city marketing in Latin American contexts, understanding that culture has differential features that could favor or hinder the promotion and sale of cities.

Along the same line, the presence of the word «resident» among the most frequently used terms raises research opportunities, since the perception of residents is important as they permeate their opinion towards tourists making them actively involved participants in the construction of the city brand.

Thus, this analysis confirms the necessity for more studies to establish the role played by citizens, regions, cities, and Latin American countries in the establishment of a city marketing policy, since its construction should not be the sole responsibility of the local administration, but of all stakeholders.

The importance of qualitative studies, observation, and case studies stems from the fact that they offer the opportunity to continue this same line in Latin American contexts; however, it also poses new challenges. There is a need for empirical studies that establish relationships among variables that may positively or negatively affect the processes of city marketing. In addition, it is also possible to develop research that empirically explores the perceptions and attitudes of stakeholders -tourists, residents, and investors- regarding the city marketing strategies implemented in Latin American cities.

On the other hand, less frequently used terms indicate those topics that are just beginning to generate interest within the global scientific community. In other words, these concepts may offer research opportunities for those who are interested in city marketing. In this sense, future studies should analyze the influence that city marketing strategies have on individuals or organizations that come to cities with the goal of investing. It would also be advisable to develop research that compares the effectiveness of various city marketing strategies among cities that share similar characteristics.
There is a need to advance studies that establish relationships between urban policy and city marketing strategies. From this same perspective, it would be interesting to consider the possible relationship between city marketing strategies and political marketing strategies. That is to say, how the creation of the identity and image of the city can favor the image of a candidate or ruler.

Finally, the study evidences the importance of analyzing the role of the diversity of fauna and flora in the cities, as well as the scenarios that are dedicated to art, in the creation of a plan of action for the construction of a city marketing strategy.

\subsection{Limitations}

This research was developed with information drawn from the Web of Science academic database. There must be papers on city marketing in other academic and/or managerial databases; therefore, future research should carry out similar processes in the context of other databases, as for example Scopus.

\section{References}

Ahn, Y.; Hyun, S.; Kim, I. (2016). City residents' perception of MICE city brand orientation and their brand citizenship behavior: a case study of Busan, South Korea. Asia Pacific Journal of Tourism Research, 21(3), 328-353. DOI: https:// doi.org/10.1080/10941665.2015.1050422

Anttiroiko, A. (2015). City branding as a response to global intercity competition. Growth and Change, 46(2), 233-252. DOI: https://doi.org/10.1111/grow.12085

Bell, D.; Binnie, J. (2004). Authenticating queer space: citizenship, urbanism and governance. Urban Studies, 41(9), 1807-1820. DOI: https://doi.org/10.1080/0042098042000243165

Cadavid, L.; Awad, G.; Franco, C. (2012). Análisis bibliométrico del campo modelado de difusión de innovaciones. Estudios Gerenciales, 28(EE), 213-236. DOI: https://doi. org/10.18046/j.estger.2012.1486

Capone, F.; Lazzeretti, L. (2016). Fashion and city branding: an analysis of the perception of Florence as a fashion city. Journal of Global Fashion Marketing, 7(3), 166-180. DOI: https://doi. org/10.1080/20932685.2016.1166715 
Casidy, R.; Wymer, W. (2015). The impact of brand strength on satisfaction, loyalty and WOM: an empirical examination in the higher education sector. Journal of Brand Management, 22(2), 117-135. DOI: https://doi.org/10.1057/bm.2015.6

Chan, C.; Peters, M.; Marafa, L. (2015). Public parks in city branding: perceptions of visitors vis-à-vis residents in Hong Kong. Urban Forestry \& Urban Greening, 14(4), 1157-1165. DOI: https://doi.org/10.1016/j.ufug.2015.10.016

Dai, T.; Hein, C.; Zhang, T. (2019). Understanding how Amsterdam City tourism marketing addresses cruise tourists' motivations regarding culture. Tourism Management Perspectives, 29, 157-165. DOI: https://doi.org/10.1016/j. tmp.2018.12.001

D'Alessandro, L.; Sommella, R.; Vigagnoni, L. (2015). Filminduced tourism, city-branding and place-based image: the cityscape of Naples between authenticity and conflicts. Almatourism-Journal of Tourism, Culture and Territorial Development, 6(4), 180-194.

De Jong, M.; Hoppe, T.; Noori, N. (2019). City Branding, Sustainable Urban Development and the Rentier State. How Do Qatar, Abu Dhabi and Dubai Present Themselves in the Age of Post Oil and Global Warming?. Energies, 12(9), 1657. DOI: https://doi.org/10.3390/en12091657

Dinnie, K. (2011). The ethical challenge. En N. Morgan; A. Pritchard; A. Pride (Comp.) Destination brands: managing place reputation. (2a ed., 69-80). Oxford: Elsevier. DOI: https://doi.org/10.1016/B978-0-08-096930-5.10005-9

Dril, N.; Galkin, A.; Bibik, N. (2016). Applyng city marketing as a tool support sustainable development in small cities: case study in Ukraine. Transportation Research Procedia, 16, 46-53. DOI: https://doi.org/10.1016/j.trpro.2016.11.006

Durieux, V.; Gevenois, P. (2010). Bibliometric Indicators: quality measurements of scientific publication. Radiology, 255(2), 342-351. DOI: https://doi.org/10.1148/radiol.09090626

Eshuis, J.; Braun, E.; Klijn, E.; Zenker, S. (2018). The differential effect of various stakeholder groups in place marketing. Environment and Planning C: Politics and Space, 36(5), 916936. DOI: https://doi.org/10.1177/2399654417726333

Fan, H.; Poshinova, A. (2016). Beijing capitalness and related challenges-Russian media perspective. Place Branding and Public Diplomacy, 12(1), 32-45. DOI: https://doi. org/10.1057/pb.2015.17

Goovaerts, P.; van Biesbroeck, H.; Tilt, T. (2014). Measuring the effect and efficiency of city marketing. Procedia Economics and Finance 12, 191-198. DOI: https://doi.org/10.1016/S22125671(14)00335-9

Green, A.; Grace, D.; Perkins, H. (2016). City branding research and practice: an integrative review. Journal of Brand Management, 23(3), 252-272. DOI: https://doi. org/10.1057/bm.2016.8
Grubbauer, M. (2014). Architecture, economic imaginaries and urban politics: the office tower as socially classifying device. International Journal of Urban and Regional Research, 38(1), 336-359. DOI: https://doi.org/10.1111/1468-2427.12110

Hassen, I.; Giovanardi, M. (2018). The difference of «being diverse »: city branding and multiculturalism in the «Leicester Model». Cities, 80, 45-52. DOI: https://doi.org/10.1016/j. cities.2017.06.019

Henninger, C.; Foster, C.; Alevizou, P.; Frohlich, Ch. (2016). Stakeholder engagement in the city branding process. Place Branding and Public Diplomacy, 12(4), 285-298. DOI: https:// doi.org/10.1057/s41254-016-0002-1

Homan, S.; O’Hanlon, S.; Strong, C.; Tebbutt, J. (2017). In Melbourne tonight: pop/rock histories and futures. Perfect Beat, 18(2), 95-109. DOI: https://doi.org/10.1558/ prbt.32801

Hospers, G. (2010). Lynch's the image of the city after 50 years: city marketing lessons from an urban planning classic. European Planning Studies, 18(12), 2073-2081. DOI: https:/ / doi.org/10.1080/09654313.2010.525369

Insch, A.; Stuart, M. (2015). Understanding resident city brand disengagement. Journal of Place Management and Development, 8(3), 172-186. DOI: https://doi.org/10.1108/JPMD-062015-0016

Kavaratzis, M.; Ashworth, G. (2005). City branding: an effective assertion of identity or a transitory marketing trick? Tijdschrift voor Economische en Sociale Geografie, 96(5), 506-514. DOI: https://doi.org/10.1111/j.1467-9663.2005.00482.x

Kavaratzis, M.; Ashworth, G. (2007). Partners in coffeeshops, canals and commerce: marketing the city of Amsterdam. Cities, 24(1), 16-25. DOI: https://doi.org/10.1016/j. cities.2006.08.007

Kavaratzis, M.; Hatch, M. (2013). The dynamics of place brands: an identity-based approach to place branding theory. Marketing Theory, 13(1), 69-86. DOI: https://doi. org/10.1177/1470593112467268

Kavaratzis, M.; Kalandides, A. (2015). Rethinking the place brand: the interactive formation of place brands and the role of participatory place branding. Environment and Planning A: Economy and Space, 47(6), 1368-1382. DOI: https://doi. org/10.1177/0308518X15594918

Klijn, E.; Eshuis, J.; Braun, E. (2012). The influence of stakeholder involvement on the effectiveness of place branding. Public Management Review, 14(4), 499-519. DOI: https://doi.org/ 10.1080/14719037.2011.649972

Kotler, P.; Gertner, D. (2002). Country as brand, product, and beyond: a place marketing and brand management perspective. Journal Brand Management, 9(4), 249-261.DOI: https://doi.org/10.1057/palgrave.bm.2540076 
Kozak, P.; Buric, M.; Policar, T.; Hamackova, J.; Lepicova, A. (2007). The effect of inter- and intra-specific competition on survival and growth rate of native juvenile noble crayfish Astacus astacus and alien spiny-cheek crayfish Orconectes limosus. Hydrobiologia, 590(1), 85-94. DOI: https://doi. org/10.1007/s10750-007-0760-0

Lu, H.; De Jong, M. (2019). Evolution in city branding practices in China's Pearl River Delta since the year 2000. Cities, 89, 154166. DOI: https://doi.org/10.1016/j.cities.2019.01.026

Lu, H.; De Jong, M.; Chen, Y. (2017). Economic city branding in China: the multi-level governance of municipal selfpromotion in the greater pearl river Delta. Sustainability, 9(4), 1-24. DOI: https://doi.org/10.3390/su9040496

Lucarelli, A.; Olof, P. (2011). City branding: a state-ofthe-art review of the research domain. Journal of Place Management and Development, 4(1), 9-27. DOI: https://doi. org/10.1108/17538331111117133

Luque, T.; del Barrio S.; Ibánez, J.; Rodríguez, M. (2007). Modeling a city's image: the case of Granada. Cities, 24(5), 335-352. DOI: https://doi.org/10.1016/j.cities.2007.01.010

Martens, C.; Lacerda, F.; Belfort, A.; Rodríguez, H. (2016). Research on entrepreneurial orientation: current status and future agenda. International Journal of Entrepreneurial Behaviour and Research, 22(4), 556-583. DOI: https://doi. org/10.1108/IJEBR-08-2015-0183

Mazzucato, M. (2011). The entrepreneurial state. Barcelona: Penguin. DOI: https://doi.org/10.3898/136266211798411183

McCann, E. (2013). Policy boosterism, policy mobilities, and the extrospective city. Urban Geography, 34(1), 5-29. DOI: https://doi.org/10.1080/02723638.2013.778627

Merrilees, B.; Miller, D.; Herington, C. (2009). Antecedents of residents' city brand attitudes. Journal of Business Research, 62(3), 362-367. DOI: https://doi.org/10.1016/j. jbusres.2008.05.011

Merrilees, B.; Miller, D.; Herington, C. (2012). Multiple stakeholders and multiple city brand meanings. European Journal of Marketing, 46(7/8), 1032-1047. DOI: https://doi. org/10.1108/03090561211230188

Misic, K.; Podnar, K. (2019). Perception of city management, fellow residents, and perceived external prestige (PEP) as antecedents of city affective commitment-the city marketing perspective. Cities, 84, 66-74.DOI: https://doi.org/10.1016/j. cities.2018.04.016

Molina, A.; Fernández, A.; Gómez, M.; Aranda, E. (2017). Differences in the city branding of European capitals based on online vs. offline sources of information. Tourism Management, 58, 28-39. DOI: https://doi.org/10.1016/j. tourman.2016.10.005
Murwani, I.; Melati, A. (2018). Adaptation of corporate identity model (AC2ID Test) to measure a city identity-case of Bandung, Indonesia. Pertanika Journal of Social Science And Humanities, 26(T), 281-296.

Nagy, A. J. (2015). City marketing in the context of economic restructuring in Manchester. Ter Es Tarsadalom, 29(4), 97115. DOI: https://doi.org/10.17649/TET.29.4.2693

Oguztimur, S.; Akturan, U. (2016). Synthesis of city branding literature (1988-2014) as a research domain. International Journal of Tourism Research, 18(4), 357-372. DOI: https:// doi.org/10.1002/jtr.2054

Okubo, Y. (1997). Bibliometric indicators and analysis of research systems: methods and examples. París: Organisation for Economic Co-Operation and Development. DOI: https:// doi.org/10.1787/208277770603

Osorio, C. (2019). Características de las publicaciones online que impulsan la generación y/o difusión de eWOM: caso de la industria del fitness (Tesis de maestría). Universidad del Valle. Cali, Colombia.

Petrea, R.; Petrea, D.; Olau, P.; Filimon, L. (2013). Place branding as efficient management tool for local government. Transylvanian Review of Administrative Sciences, (SI), 124-140.

Rehmet, J.; Dinnie, K. (2013). Citizen brand ambassadors: motivations and perceived effects. Journal of Destination Marketing \& Management, 2(1), 31-38. DOI: https://doi. org/10.1016/j.jdmm.2013.02.001

Rey-Martí, A.; Ribeiro-Soriano, D.; Palacios-Marqués, D. (2016). A bibliometric analysis of social entrepreneurship. Journal of Business Research, 69(5), 1651-1655. DOI: https://doi. org/10.1016/j.jbusres.2015.10.033

Sassmannshausen, S.; Volkmann, C. (2013). A bibliometric based review on social entrepreneurship and its establishment as a field of research. Schumpeter Discussion Papers. Recuperado de https://bit.ly/2OtWhNI

Short,J. (2018). The unequal city. Urban resurgence, displacement and the making or inequality in global cities. Nueva York: Routledge Group. DOI: https://doi.org/10.4324/9781315272160

Smyth, H. (2005). Marketing the city: the role of flagship developments in urban regeneration. Londres: Taylor \& Francis.

Trueman, M.; Klemm, M.; Giroud, A. (2004). Can a city communicate? Bradford as a corporate brand. Corporate Communications: An International Journal, 9(4), 317-330. DOI: https://doi.org/10.1108/13563280410564057

Urbizagástegui, R. (2015). El crecimiento de la literatura sobre la ley de Bradford. Investigación Bibliotecológica: Archivonomía, Bibliotecológica e Información, 30(68), 51-72. DOI: https:// doi.org/10.1016/j.ibbai.2016.02.003 
Vanolo, A. (2008). The image of the creative city: some reflections on urban branding in Turin. Cities, 25(6), 370-382. DOI: https://doi.org/10.1016/j.cities.2008.08.001

Van Roy, V. (2007). Belgian beer tourism as a type of concept of the Hedendaag «glocalisation tendency». Volkskunde, $108(2), 125$.

Waltman, L.; van Eck, N. (2015). Field-normalized citation impact indicators and the choice of an appropriate counting method. Journal of Informetrics, 9(4), 872-894. DOI: https:// doi.org/10.1016/j.joi.2015.08.001

Zenker, S.; Braun, E. (2017). Questioning a «one size fits all» city brand: developing a branded house strategy for place brand management. Journal of Place Management and Development, 10(3), 270-287. DOI: https://doi.org/10.1108/JPMD-042016-0018

Zenker, S.; Petersen, S. (2014). An integrative theoretical model for improving resident-city identification. Environment and Planning A-Economy And Space, 46(3), 715-729. DOI: https://doi.org/10.1068/a46191

Zhang, L.; Zhao, S. (2009). City branding and the olympic effect: a case study of Beijing. Cities, 26(5), 245-254. DOI: https:// doi.org/10.1016/j.cities.2009.05.002 